\title{
Study of historical groundwater level changes in two Belgian chalk aquifers in the context of climate change impacts
}

\author{
Pascal Goderniaux $^{1}$, Philippe Orban ${ }^{2}$, Alain Rorive ${ }^{1}$, Serge Brouyère $^{2}$, Alain Dassargues ${ }^{2}$ \\ ${ }^{1}$ Geology and Applied Geology, Polytech Mons, University of Mons, Mons, Belgium \\ ${ }^{2}$ Hydrogeology \& Environmental Geology, Urban \& Environmental Engineering, University \\ of Liège, Belgium \\ * Corresponding author (e-mail: Pascal.Goderniaux@umons.ac.be)
}

\begin{abstract}
In Southern Belgium, 23\% of abstracted groundwater volumes are from chalk aquifers which represent strategic resources for the region. Due to their specific nature, these chalk aquifers often exhibit singular behaviour and require specific analysis. The quantitative evolution of these groundwater resources is analysed for the Mons Basin and Hesbaye chalk aquifers as a function of past evolution, in the short and long terms. Groundwater level time series exhibit decreases when analysed over different periods. This is particularly visible for the Hesbaye chalk aquifer when comparing the 1960-1990 and 1990-2020 periods. Such decreases are associated to observed temperature increase and a precipitation decrease, inducing a decrease of aquifer recharge, and a probable increase of groundwater abstraction in the adjacent catchment. Past evolution is also discussed considering recent winter and summer drought events. The aquifers exhibit long delays in response to recharge events, particularly where the thickness of the partially saturated zone plays a crucial role in observed delays. Regarding future evolution, simulations of the impact of climate changes using medium-high emission scenarios indicate a probable decrease of the groundwater levels over the Hesbaye chalk aquifer.
\end{abstract}

\section{Introduction}

In Southern Belgium (Wallonia), 23\% of abstracted groundwater volumes are from chalk aquifers (SPW 2020). These chalk geological formations thus represent strategic aquifers for drinking water supply in the region.

Due to their specific hydraulic properties, chalk aquifers often exhibit singular behaviours where the large matrix porosity enables storage of large quantities of groundwater and the fractures and fissures allow drainage and fast preferential groundwater flow. This duality in terms of permeability and porosity induces challenges related to aquifer characterization and particularities regarding the evolution of groundwater levels (Brouyère et al. 2004, Goderniaux et al. 2015, Goderniaux et al. 2018), solute transport (Orban et al. 2010, Hakoun et al. 2017, Hoffmann et al. 2020) or even with regards to more recent applications such as energy storage. Because of their strategic importance and because climate is currently changing, studying the resilience of chalk aquifers during drought periods is crucial. It allows the implementation of efficient management strategies to perpetuate effective and robust water supply in the future.

In this paper, an overview of chalk aquifers from Southern Belgium, the Mons Basin and the Hesbaye aquifers is undertaken, focussing on groundwater quantity. In particular, the quantitative evolution of these groundwater resources is analysed as a function of past and 
future climate conditions, in the short and long terms. Impacts are also discussed in light of the 2016-2019 period characterized by winter and summer drought events in Belgium.

\section{Hydrogeological context of chalk aquifers in Southern Belgium}

The chalk aquifers in Belgium have been described by Dassargues \& Monjoie (1993), Hallet (1998), Rorive and Goderniaux (2014), Orban et al. (2014). Various types of chalks are represented in Belgium, those from Turonian to Maastrichtian ages can be found in the Mons Basin and in the Tournai area, and Campanian to Maastrichtian chalks are found in northeastern Belgium, in the region of Herve, in the Hesbaye region near Liège, in Northern Brabant and in the Kampen.

\section{The chalk aquifer of the Mons sedimentary Basin (or Haine valley)}

The chalk aquifer of the Mons Basin is located in South-Western Belgium (Figure 1A) within Cretaceous strata accumulated due to the subsidence of the sedimentary basin. The extent of the aquifer $\left(403 \mathrm{~km}^{2}\right)$ corresponds approximately to the catchment of the Haine River, which is mainly oriented along an East-West direction.

The chalk aquifer is composed of different geological formations, mainly chalk sensu stricto but also some calcarenite and tuffeau layers. The geological formations form a 10 to $15 \mathrm{~km}$ wide syncline-shape structure oriented East-West. The total thickness of the aquifer may reach more than $300 \mathrm{~m}$ in the central part of the sedimentary basin.

The base of the aquifer consists of marl layers. The aquifer is considered as unconfined in the Northern, Southern and Eastern parts of the basin. It is considered as confined or semiconfined in the central part, along the Haine River, where the chalk layers are covered by some Cenozoic clay and sand deposits $\left(168 \mathrm{~km}^{2}\right)$.

From a hydrogeological perspective, the different chalk geological layers are usually grouped in thicker hydrogeological units, characterized by similar hydraulic properties. The mean hydraulic conductivity of those aquifer units ranges from $10^{-6}$ to $10^{-4} \mathrm{~m} / \mathrm{s}$, mainly depending on the level of fracturation of the chalk rocks. From a general and regional perspective, groundwater flows from the Northern and Southern limits of the aquifer to the Haine River in the center of the basin (Figure 1A and Figure 2A) (Rorive \& Goderniaux 2014). The average direct and indirect recharge of the aquifer is estimated to be $81 \times 10^{6} \mathrm{~m}^{3} /$ year for the period 1970-1982. Groundwater resources are intensely exploited, mostly for drinking water production. Abstracted volumes correspond to about $60 \%$ of the annual recharge (Rorive, 1983). A significant part of the abstracted groundwater is exported to supply other regions with drinking water, in particular the city of Brussels.

\section{The Hesbaye chalk aquifer}

The Hesbaye chalk aquifer is located in eastern Belgium (Figure 1B - 596 km²) to the northwest of the city of Liège within Cretaceous chalk strata. The 'smectite de Herve' which is a calcareous clay layer of 2 to $10 \mathrm{~m}$ thick is considered as the aquifer low permeability base above Palaeozoic strata. From bottom to the top, the chalk sequence consists of 20 to $40 \mathrm{~m}$ of compact Campanian chalk locally fractured, a thin (about $1 \mathrm{~m}$ ) hardened layer of Campanian chalk (called the Froidmont Hardground), and 10 to $15 \mathrm{~m}$ of weathered and fractured Maastrichtian chalk. Above the chalk, a 2 to $9 \mathrm{~m}$ thick residual conglomerate is found, overlaid by 2 to $20 \mathrm{~m}$ of Cenozoic sands and Quaternary loess. In the Geer valley located in the North of the Hesbaye region, up to $5 \mathrm{~m}$ of recent alluvial and colluvial deposits, are observed. The extent of the unconfined part of the aquifer corresponds more or less to the 
Geer river basin. Due to a slight dip of the geological strata to the North, the aquifer becomes confined to the North of the Geer basin under clayey Cenozoic sediments. In the Geer basin, the chalk is covered by a thick layer of loess that plays a key role in the infiltration of water and pollutants to the aquifer (Batlle-Aguilar et al. 2007).

From a regional perspective, groundwater flows mainly from the South to the North. However, in the eastern part of the Geer basin, groundwater flows towards the Geer river (Figure 2B) (Orban et al. 2014). About $25 \times 10^{6} \mathrm{~m}^{3}$ of groundwater production is recorded by drainage in $45 \mathrm{~km}$ of galleries (red lines in Fig. 1B) and by pumping in water wells (red squares in Fig. 1B). This amount represents about $10 \%$ of the mean annual rainfall and about 30 to $50 \%$ of the estimated recharge. Different groundwater modelling works have been used for the groundwater quantity and quality management of this aquifer (Dassargues et al. 1988, Bolly et al. 1988, Orban, 2010) and for the evaluation of different climate change scenarios (Brouyère et al. 2004, Goderniaux et al. 2015)

\section{Analysis of long-term groundwater level time series}

Groundwater levels have been monitored over the two aquifers for several decades. Figure 2A and B shows maps of groundwater monitoring stations along with the calculated ranges of groundwater variations (difference between maximum and minimum values) over the period $1990-2020$. The intervals of groundwater head variations logically increase with the distance to the main draining rivers.

Figure 2C and Figure 2D show two examples of evolutions of groundwater levels in recharge zones of both aquifers. The locations of the two related piezometers are indicated in yellow in Figure 1. Time series are provided along with estimated annual recharge rates calculated using the Thornthwaite algorithm, using data from the meteorological stations 'La Hestre' and 'Bierset' for the Mons Basin and Hesbaye aquifer, respectively. Recharge values consequently corresponds to recharge rates just below the evaporation and root zones. Runoff is neglected in those quite flat and infiltrative areas. This may lead to overestimation of recharge, especially during summers when extreme stormy rainfall events are frequently observed. Over the period 1990-2020, the mean annual recharge is equal to $217 \mathrm{~mm} /$ year and $117 \mathrm{~mm} /$ year in the Mons Basin and Hesbaye aquifers, respectively.

In the chalk aquifer of the Mons Basin, clear seasonal and multi-annual variations are visible. Groundwater levels are generally correlated with recharge rates with a very short time delay. A maximum delay of 3 months is observed in the South-East area of the aquifer, where the partially saturated zone become thicker, with a maximum thickness of $40 \mathrm{~m}$.

In the Hesbaye aquifer, the evolution of groundwater levels is different. Due the thick layer of loess and the thick unsaturated zone, the delay observed between precipitations and variations in groundwater levels can be long, ranging from a few weeks to one year and a half.

\section{Fluctuations of groundwater levels do not show seasonal variations and clearly allow} distinguishing contrasted periods of high and low groundwater levels such as those existing in 1983-1984 and 1991-1992. On the other hand, a general decrease in groundwater levels can be observed in Figure 2D between 1983 and nowadays, as illustrated by the mean groundwater level that is shifted downwards for the period 1990-2020 compared to the period 1960-1990 (Figure 2F). This decrease is generally observed throughout the basin although the intensity may vary according to the local context or the proximity of specific hydrogeological limits. 
139 Figure 2E and Figure 2F compare groundwater level and recharge over different time periods.

140 For the Hesbaye aquifer, the comparison is performed for the two 30-year non-overlapping

141 1960-1990 and 1990-2020 intervals. Those 30-year time periods aim to discriminate the impact of climate change to that of meteorological conditions. For the Mons Basin aquifer, intervals are shorter and partly superimposed (1986-2005 and 2000-2020), due the lack of continuous meteorological time series. Figure $2 \mathrm{E}$ and Figure $2 \mathrm{~F}$ show monthly mean groundwater levels of the two piezometers highlighted in yellow in Figure 1, and monthly mean recharge rates for all calendar months. A seasonal behaviour is visible in Figure 2E (Mons Basin), showing a slightly delayed increase in groundwater levels compared to the recharge period. In Figure 2F (Hesbaye), the seasonal behaviour is almost imperceptible, in accordance with the piezometric evolution presented previously.

A clear groundwater level decrease of about $6 \mathrm{~m}$ is observed for the Hesbaye aquifer (Figure 2F). Several reasons may explain such decreases. Figure $2 \mathrm{G}$ and Figure $2 \mathrm{H}$ show precipitation and temperature monthly statistics for the investigated periods. For the Hesbaye chalk aquifer, an increase of temperature is observed for all months of the calendar, with a maximum value of about $+2^{\circ} \mathrm{C}$ in summer. Decrease of precipitation rates are also observed, especially at the end of fall and the end of winter. These changes clearly impact mean groundwater recharge values during winter and spring (Figure 2F). For the period 1960-1990, groundwater recharge is estimated to $207 \mathrm{~mm} /$ year, and for the period 1990-2020, the same calculation leads to a recharge of $117 \mathrm{~mm} /$ year only (Figure 2D). This significant reduction in the recharge rate has a direct influence on groundwater levels. In addition, the Hesbaye chalk units are continuous towards the North beyond the Geer catchment basin. Important withdrawals by pumping operated outside this basin, are usually not included in the water balance. Significant groundwater flows leave the Geer watershed across this northern border.

with

The groundwater balance in this catchment can be expressed as:

- $P$

- $Q_{\text {Geer }}$

- Qpumping

- $\Delta$ Res

- Losses

$$
P=E T R+Q_{\text {Geer }}+Q_{\text {pumping }}+\Delta \text { Res }+ \text { Losses }
$$

mean precipitation value mean discharge of the Geer River at the outlet of the catchment mean groundwater abstraction by drainage galleries and pumping wells change of groundwater reserves over the considered period due to groundwater level changes water balance 'error' essentially considered as losses through the northern boundary of the catchment.

Over the 1951-1965 and 1975-1994 time intervals, the balance terms are equal to (Hallet 1998, Orban et al. 2014):

Comparing the two periods, losses increase to reach about $7 \%$ of the total groundwater

180 balance, suggesting an increase of the transfers through the northern limit of the basin, which

181 could also influence the time evolution of groundwater levels in the Geer basin.

182 Unfortunately, no recent calculation of the water balance is available. However, over the 
investigated time period, groundwater production has been relatively constant in the Geer basin, while an increase of water production by pumping has been observed in the confined part of the chalk aquifer outside the Geer basin and especially in the south of the Limburg province of Belgium (VMM, 2019). This increase of groundwater production was recently further reenforced by the addition of new pumping wells in the neighbouring area of the Geer basin (Six, 2017).

For the Mons Basin aquifer, decrease of groundwater levels and increase of temperatures are also observed for all calendar months. The impact of climate change on recharge and groundwater levels is also possible. Conclusions are nevertheless difficult to draw because the comparison is based on shorter and partly overlapping time intervals.

\section{Analysis of short-term groundwater level time series in the context of droughts}

Since October 2016, groundwater recharge rates have been characterized by low values, compared to the mean value calculated over the period 1990-2020 (Figure 2C and Figure 2D). Such lower recharge rates are mainly explained by lower precipitations during the recharge periods. Hot and dry summers were also observed but they theoretically do not impact directly recharge. They can however contribute to increase the water demand during summers. These lower recharge rates have induced significant decreases in groundwater levels in the two chalk aquifers, and generally in Southern Belgium. This decrease is particularly visible during the hydrological year 2016-2017 for the Mons Basin aquifer, and with a delay of a few months for the Hesbaye aquifer. During this period and in many places, groundwater levels have been close to their lowest levels measured anytime in the past.

During winter 2019-2020, a higher recharge and partial recovery of groundwater levels was generally observed in most aquifers. In the two studied chalk aquifers, this recovery is heterogeneous, depending on the aquifer hydrogeological context and the thickness of the partially saturated zone, which controls infiltrations from the ground surface to the groundwater table. Figure 3 shows the state of groundwater levels in May 2020, compared to all months of May within the period 1990-2020. The month of May is considered for the comparison because it approximately corresponds to the end of the recharge period. The indicator shown in Figure 3 is calculated as the difference between the groundwater level in May 2020 and the mean groundwater level among all months of May within 1990-2020, normalized by the min-max interval (Equation 2). A negative value of the indicator, corresponding to reddish colours, means that the groundwater level in May 2020 is below average.

$$
\text { with }
$$

$$
\text { - } H_{\text {May } 2020}
$$$$
\text { - }\left.\bar{H}_{\text {May }}\right|_{1990-2020}
$$$$
\text { - }\left.\operatorname{Max}\left(H_{\text {May }}\right)\right|_{1990-2020}
$$$$
\text { - }\left.\operatorname{Min}\left(H_{\text {May }}\right)\right|_{1990-2020}
$$

Groundwater level in May 2020

Mean groundwater level in May for the period 1990-2020

Max groundwater level in May for the period 1990-2020

Min groundwater level in May for the period 1990-2020 
The values and spatial distribution of the indicator are different in the two studied aquifers. In the Mons Basin aquifer, about two-third of the values are positive or close to zero, except in the areas with a thicker partially saturated zone (South-East). Groundwater levels generally benefited from normal recharge rates during winter 2019-2020. In the Hesbaye chalk aquifer, values are strongly negative in most of the locations, indicating that groundwater levels still remain low, demonstrating a stronger inertia in this aquifer and probably a different behaviour due to the increase of groundwater production from the chalk aquifer in the northern area outside the Geer basin (see above).

\section{Climate change impact on groundwater resources}

Previous sections presented the evolution and specific behavior of groundwater levels in the two chalk aquifers, in relation to past climate and weather. Nevertheless, the climate has been changing and it is expected to change further in the next decades. According to Blenkinsop et al. (2013) and Goderniaux et al. (2009), and based on Regional Climate Model (RCM) output from the FP5 PRUDENCE project (Christensen et al., 2007), temperatures in the Hesbaye region are generally expected to increase throughout the year, with hotter and dryer summers, and increased precipitations during winter months. This configuration is not easy to capture as the recharge period is affected by a simultaneous increase of precipitation and evapotranspiration, which are concurrent processes regarding groundwater recharge generation. As groundwater is strategic for drinking water distribution in Southern Belgium and Brussels city, it is crucial for water managers to know how groundwater resources may evolve in the future, including in the chalk aquifers of the Mons Basin and Hesbaye.

To answer this question and project climate change impact on groundwater resources, Goderniaux et al. (2009) developed a 3D spatially-distributed, physically-based numerical model of the Hesbaye chalk aquifer. The model was developed with the simulator HydroGeoSphere (Therrien et al. 2005) which integrates the calculation of surface flow, groundwater flows in the partially and fully saturated zones, and the actual evapotranspiration. Water exchanges between the different compartments are calculated at each time step. The integration of all processes in a unique model allows more robust and realistic simulations, with possible feedbacks between the different compartments.

The model was coupled with climate change scenarios (Blenkinsop et al. 2013) statistically downscaled from six different Regional Climate Models (RCMs) using projections corresponding to the SRES A2 emissions (medium-high) scenario (Nakicenovic et al., 2000). Equiprobable scenarios corresponding to the time interval 2010-2100 were generated for each RCM and used as input of the hydrological model.

Results generally show decreasing trends of the average simulated groundwater levels, calculated over all equiprobable scenarios. Figure 4 shows examples for 30 scenarios generated from the RCM ARPEGE. Figure 4A shows the projected changes in temperature and precipitation by the end of the century. Figure 4B presents the corresponding simulated groundwater levels at the piezometer highlighted in yellow in Figure 1. The decreasing trend of the mean simulated groundwater levels is explained by climate change. The uncertainty related to the natural variability of the weather is illustrated by all equiprobable scenarios displayed around the average behavior. This uncertainty looks higher at the end of the period. This is mainly explained by the influence of the partially saturated zone whose thickness and control on infiltrations from the ground surface to the groundwater table increase as 
groundwater levels decrease. Beside the natural variability of the weather, simulated results are also affected by other sources of uncertainty, including the climate models, and the implementation and calibration of the hydrological model. Despite these uncertainties, which make difficult the accurate impact quantification, Goderniaux et al. (2015) showed that it remains likely that groundwater levels will decrease by the end of the century.

279

\section{Conclusions}

On a middle to long-term basis, observations over the 1960-1990 and 1990-2020 periods show precipitation and temperature changes, with a negative impact on calculated recharge rates for the Hesbaye aquifer. This recharge change contributes to explain the mean groundwater level decrease observed over the two periods, although the evolution and impact of groundwater abstraction rates at a regional scale must also be considered and assessed carefully. Previous simulations on the impact of climate changes have predicted a probable decrease of the groundwater levels. New simulations with the most recent climate models and emission scenarios are being started. They will be useful for possible changes in the structural long-term water management policies.

On a short-term basis, chalk aquifers in South Belgium involve large volumes of groundwater, characterized by long delays in reaction to recharge and groundwater exploitation changes. This is particularly true in Hesbaye (Geer basin). As a consequence, the two studied aquifers represent important resources, which can probably be used as buffers to compensate temporary difficulties, such as a higher water demand during a particular summer drought, or a recharge deficit during a specific winter. The question nevertheless arises about the aquifer resilience if successive difficulties are occurring. In any case, short-term events and long-term trends should not be confused because they require different management responses.

\section{References}

Batlle-Aguilar, J., Orban, Ph., Dassargues, A. \& Brouyère, S. 2007. Identification of groundwater quality trends in a chalky aquifer threatened by intensive agriculture, Hydrogeol. J. 15: 1615-1627.

Blenkinsop S., Harpham C., Burton A., Goderniaux P., Brouyere S., Fowler H. 2013. Downscaling transient climate change with a stochastic weather generator for the Geer catchment, Belgium. Climate Research 57(2), 95-109.

Bolly, P.Y., Dassargues, A. \& Monjoie, A. 1988. Finite difference and finite element modelling of an aquifer in Cretaceous chalk, Proc. of the Sixth International Conference on Numerical Methods in Geomechanics, Innsbruck, April 1988, pp. 747-756, Balkema. Brouyère, S., Carabin, G. \& Dassargues, A. 2004. Climate change impacts on groundwater reserves: modelled deficits in a chalky aquifer, Geer basin, Belgium, Hydrogeol. J. 12(2): 123-134. http://hdl.handle.net/2268/2332

Christensen, J.H., Carter, T.R., Rummukainen, M. \& Amanatidis G. 2007. Evaluating the performance and utility of regional climate models: the PRUDENCE project. Climatic Change 81 (Suppl. 1), 1-6.

Dassargues, A., Radu, J.P. \& Charlier, R. 1988. Finite elements modelling of a large water table aquifer in transient conditions. Adv. Water Res. 11(2): 58-66.

Dassargues, A. 2018. Hydrogeology - groundwater science and engineering. CRC Press. Dassargues, A. \& Monjoie, A. 1993. Chalk as an aquifer in Belgium. In: Downing, R.A., Price, M. Jones, G.P. (eds.) The hydrogeology of the chalk of north-west Europe. Clarendon Press, Oxford. 153-169. 
Goderniaux, P., Brouyere, S., Fowler, H., Blenkinsop, S., Orban, P., Dassargues, A. 2009. Large scale surface - subsurface hydrological model to assess climate change impacts on groundwater reserves. Journal of Hydrology 373(1-2): 122-138. Uncertainty of climate change impact on groundwater reserves - Application to a chalk aquifer. Journal of Hydrology 528: 108-121. pumping and tracing experiments with packer systems. Engineering in Chalk, Proc. of the Chalk 2018 Conference, 675-680, Londres, Royaume-Uni. Hakoun, V., Orban, Ph., Dassargues, A. \& Brouyère, S. 2017. Factors controlling spatial and temporal patterns of multiple pesticide compounds in groundwater (Hesbaye chalk aquifer, Belgium). Env. Pollution 223: 185-199. Hallet, V. 1998. Étude de la contamination de la nappe aquifère de Hesbaye par les nitrates (in French), $\mathrm{PhD}$, University of Liège. Hoffmann, R. Goderniaux, P., Jamin, P., Chatton, E., de la Bernardie, J., Labasque, T., Le Borgne, T. \& Dassargues, A. 2020. Continuous dissolved gas tracing of fracture-matrix exchanges. Geophysical Research Letters (In Press). doi.org/10.1029/2020GL088944 Nakicenovic, N. et al., 2000. Emissions Scenarios. A Special Report of Working Group III of the Intergovernmental Panel on Climate Change. Cambridge University Press, Cambridge. Orban, P., Brouyère, S., Batlle-Aguilar, J., Couturier, J., Goderniaux, P., Leroy, M., Malozewski, P. \& Dassargues, A. 2010. Regional transport modelling for nitrate trend assessment and forecasting in a chalk aquifer, J. Cont. Hydrol. 118: 79-93.

Orban, P., Brouyère, S., Compère, J.-M., Six, S., Hallet, V., Goderniaux, P., \& Dassargues, A. (2014). Aquifère crayeux de Hesbaye. In A., Dassargues \& K., Walraevens (Eds.), Watervoerende lagen en grondwater in Belgïe - Aquifères et eaux souterraines en Belgique. 143-159, Belgium: Academia Press.

Rorive, A. 1983. Détermination des ressources souterraines de la nappe du Crétacé de la vallée de la Haine, FPMs (UMons)-IDEA, Etude sous contrat pour le secrétariat d'état à l'Economie Régionale Wallonne.

Rorive, A. \& Goderniaux, P. 2014. L'aquifère du Crétacé de la vallée de la Haine. In A., Dassargues \& K., Walraevens (Eds.), Watervoerende lagen en grondwater in Belgie Aquifères et eaux souterraines en Belgique. 183-190, Belgium:Academia Press. Six, S. 2017. Grondwaterwinning te Overhaam (Tongeren), Hydrogeologische studie van een nieuwe grondwaterwinning in het Krijt (in Dutch), De Watergroep, 48p.

https://www.milieuinfo.be/dms/d/d/workspace/SpacesStore/da97411e-7c30-40e2-abf0da6dc26d68de/BIJLAGE\%201\%20hydrogeologischestudie_Overhaem_05122017.pdf SPW 2020. Etat des nappes d'eau souterraine de Wallonie. Edition : Service public de Wallonie, Belgique. http://environnement.wallonie.be/de/eso/atlas/index.htm Therrien, R., McLaren, R.G., Sudicky, E.A. \& Panday, S.M. 2005. HydroGeoSphere. A threedimensional numerical model describing fully-integrated subsurface and surface flow and solute transport, 5, $343 \mathrm{pp}$.

VMM, 2019. Drinkwater voorziening in Vlaanderen: organisatie en een blik vooruit (in Dutch).65p.https://www.vmm.be/water/drinkwater/drinkwatervoorziening_in_vlaanderen_org anisatie_en_een_blik_vooruit_tw.pdf

\section{Figures}



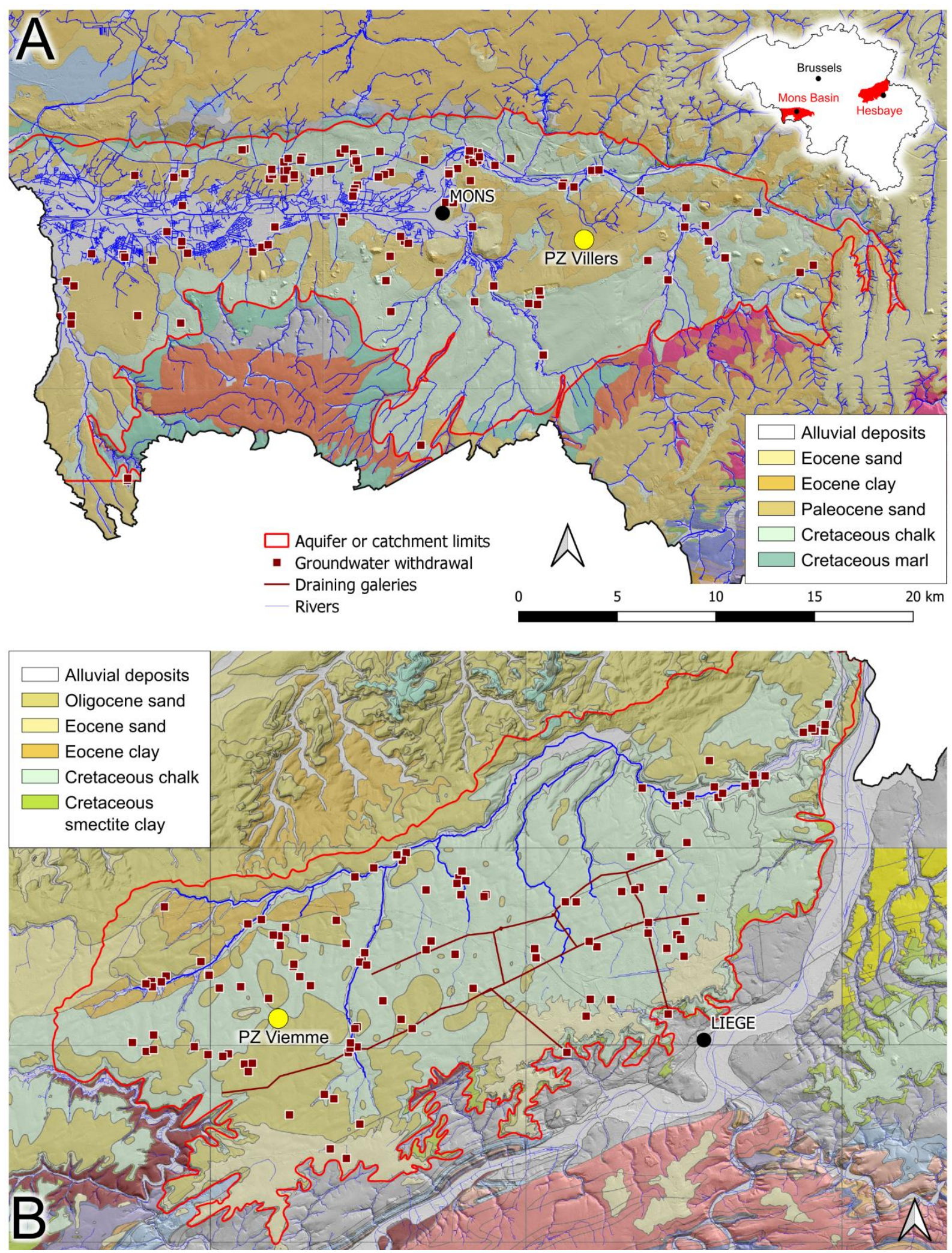

Figure 1. (A) Chalk aquifer of the Mons sedimentary Basin. (B) Chalk aquifer of Hesbaye. Legend is provided only for the hydrogeological units present within the aquifer limits. The yellow points correspond to the two piezometers discussed in Figure 2. 
Mons Basin

A

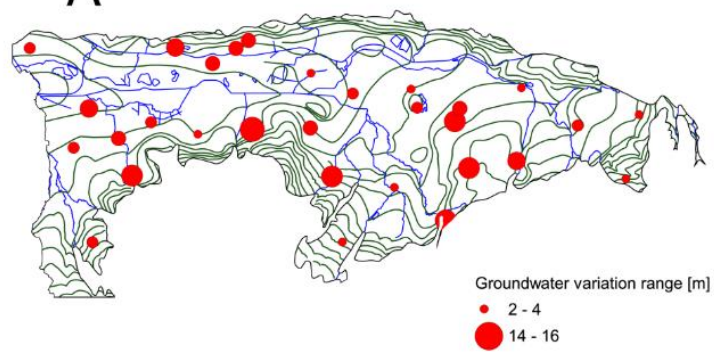

C

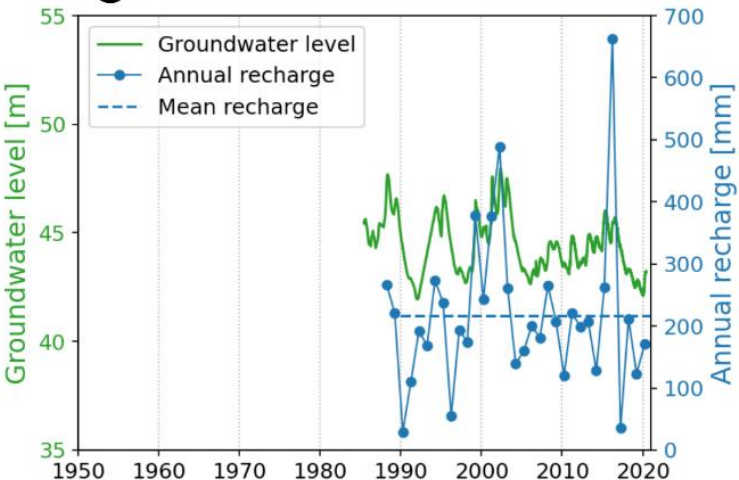

E
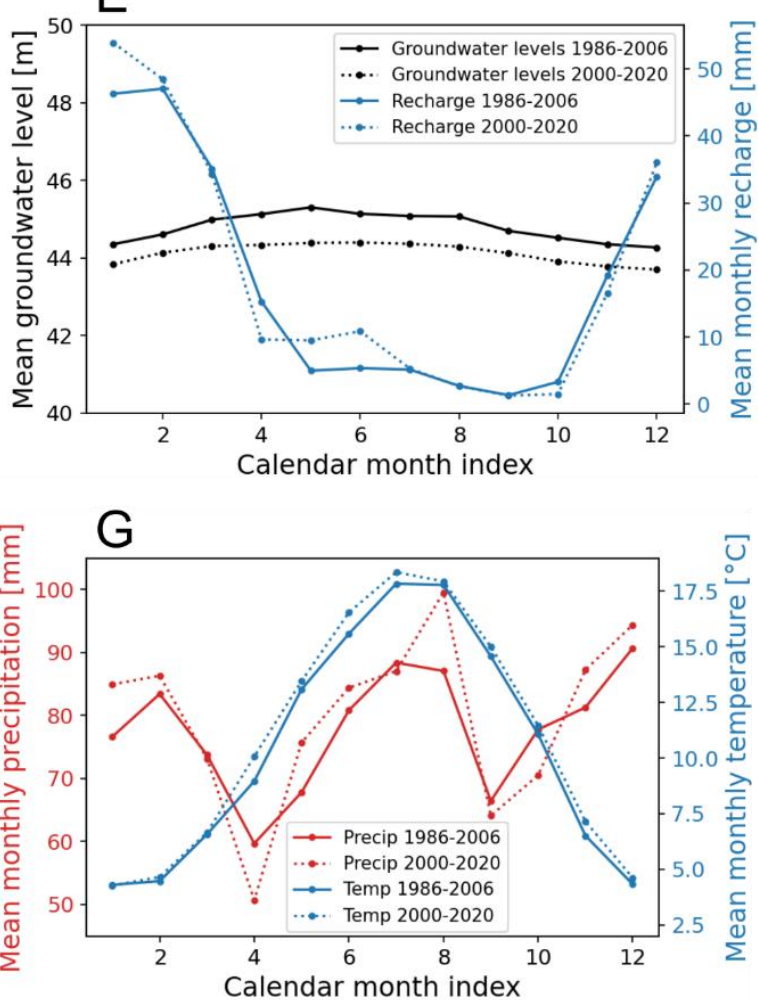

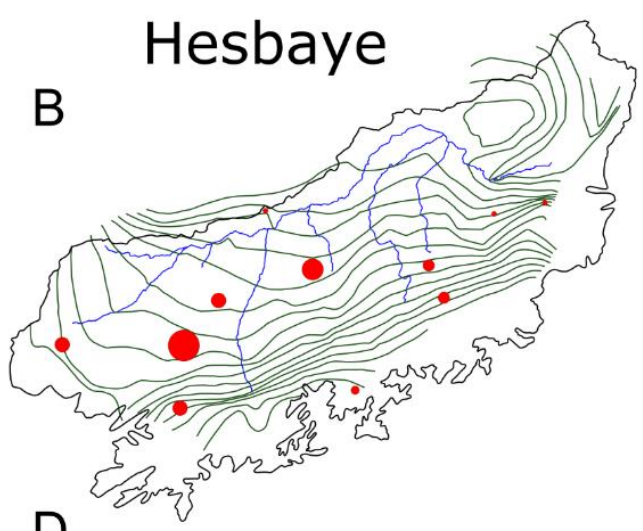

D

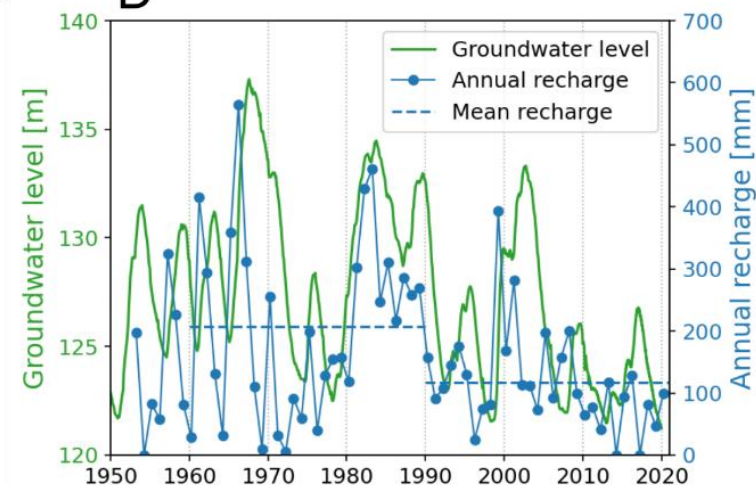

$\mathrm{F}$
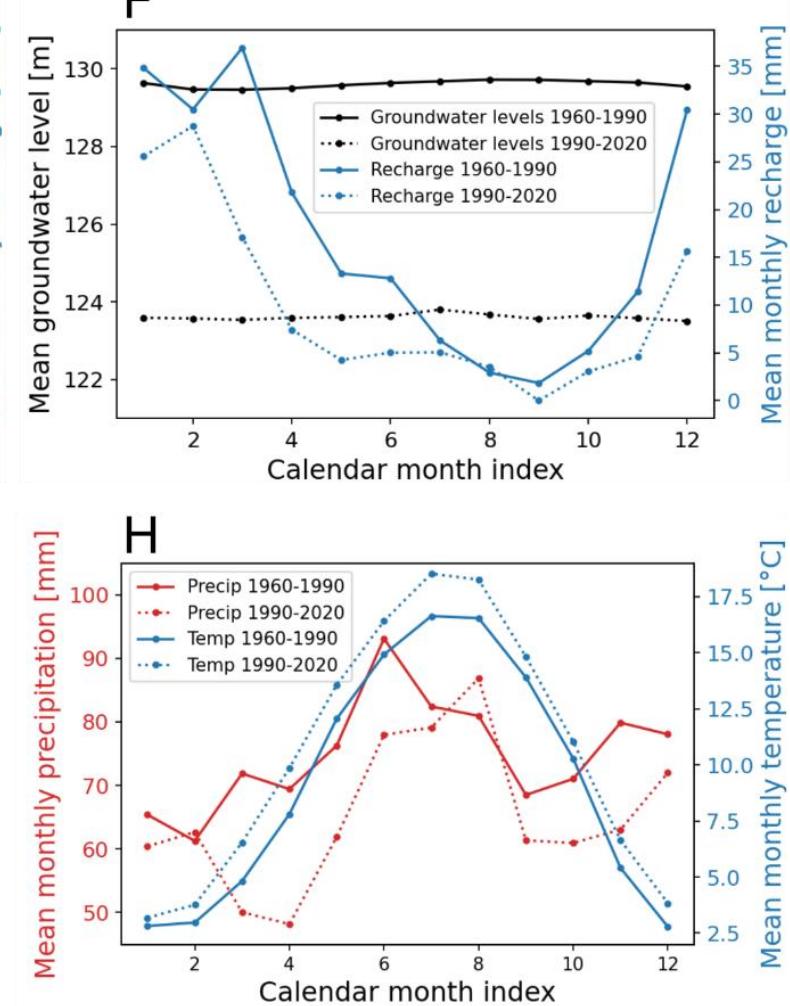

Figure 2. (A) Piezometric contours and range of groundwater variations (Max-Min) in the Mons Basin aquifer. (B) Piezometric contours and range of groundwater variations (Max-Min) in the Hesbaye aquifer. (C) Example of groundwater level evolution in the Mons Basin aquifer (PZ Villers - Figure 1A) with annual recharge values. The dotted horizontal line represents the mean annual recharge calculated over the shown period. (D) Example of groundwater level evolution in the Hesbaye aquifer (PZ Viemme - Figure $1 B)$ with annual recharge values. (E) Monthly piezometric and recharge statistics in 

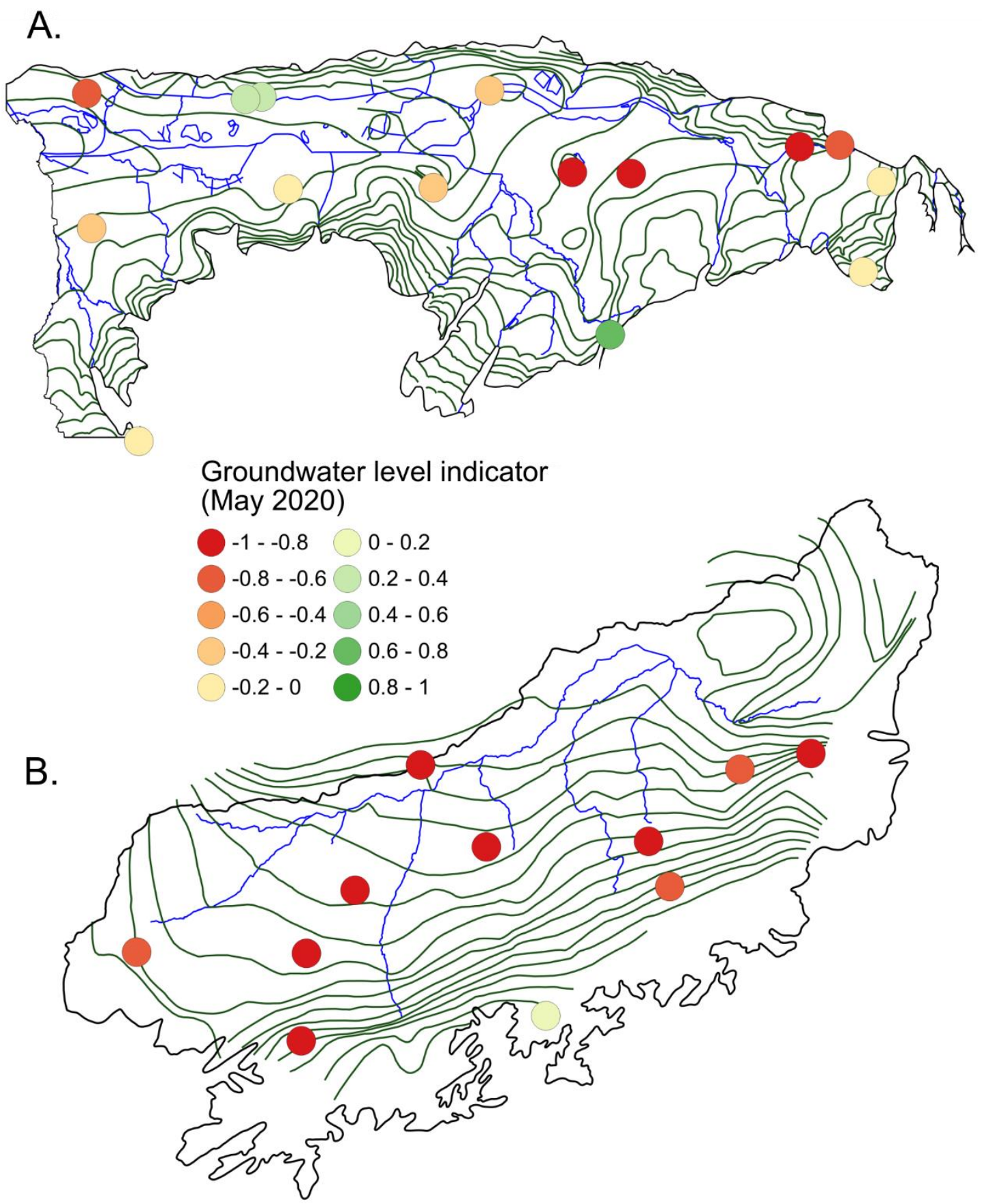

Figure 3. Spatial distribution of an indicator value showing the state of groundwater levels in May 2020, compared to all months of May within the period 1990-2020, in (A) the Mons Basin aquifer and (B) the Hesbaye aquifer. The indicator is calculated using Equation 2. 

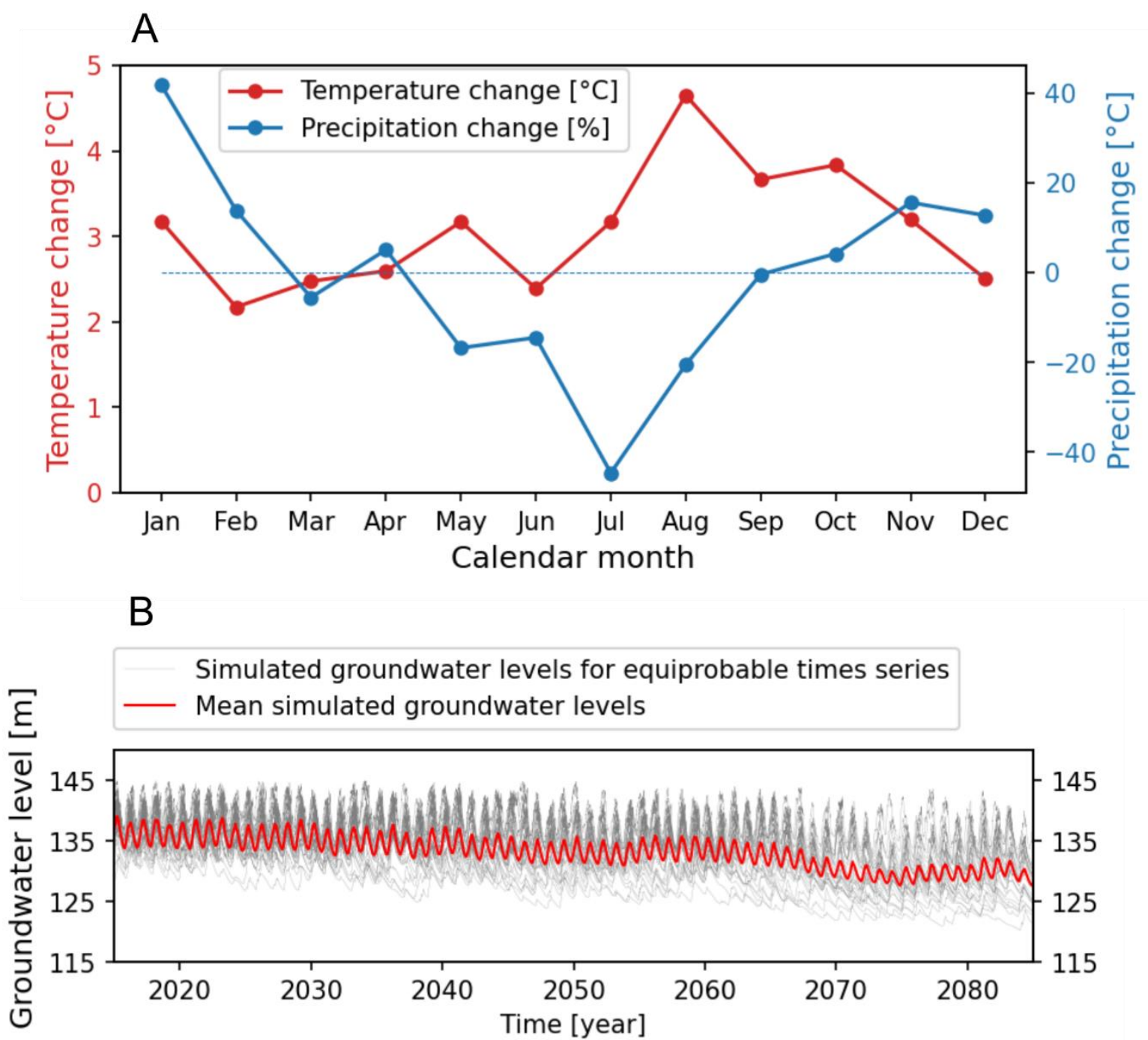

Figure 4. (A) Monthly precipitation and temperature changes from the RCM ARPEGE for the time slice 2071-2100 and corresponding to the SRES A2 emissions (medium-high) scenario. (B) Corresponding simulated groundwater levels in the Hesbaye aquifer at the level of the piezometer highlighted in Figure 1.

\section{Figure captions}

Figure 1. (A) Chalk aquifer of the Mons sedimentary Basin. (B) Chalk aquifer of Hesbaye. Legend is provided only for the hydrogeological units present within the aquifer limits. The yellow points correspond to the two piezometers discussed in Figure 2

Figure 2. (A) Piezometric curves and range of groundwater variations in the Mons Basin aquifer. (A) Piezometric curves and range of groundwater variations in the Hesbaye aquifer. (C) Example of groundwater level evolution in the Mons Basin aquifer (PZ Villers - Figure 1A) with annual recharge values. The dotted horizontal line represents the mean annual recharge calculated over the shown period. (D) Example of groundwater level evolution in the Hesbaye aquifer (PZ Viemme - Figure 1B) with annual recharge values. (E) Monthly piezometric statistics in the Mons Basin aquifer (PZ Villers). (F) Monthly piezometric statistics in the Hesbaye aquifer (PZ Viemme). (G) Monthly precipitation and temperature statistics in the Mons Basin ("La Hestre" meteo station). (H) Monthly precipitation and temperature statistics in Hesbaye ("Bierset" meteo station). 
418 Figure 3. Spatial distribution of an indicator value showing the state of groundwater levels in 419 May 2020, compared to all months of May within the period 1990-2020, in (A) the Mons Basin 420 aquifer and (B) the Hesbaye aquifer. The indicator is calculated using Equation 2.

421 Figure 4. (A) Monthly precipitation and temperature changes from the RCM ARPEGE for the 422 time slice 2071-2100 and corresponding to the SRES A2 emissions (medium-high) scenario. 423 (B) Corresponding simulated groundwater levels in the Hesbaye aquifer at the level of the 424 piezometer highlighted in Figure 1. 